\title{
Deoxycytidylate Deaminase in Pregnancy
}

\author{
G. F. WILLIAMS， D. D. JONES
}

British Medical fournal, 1975, 2, 10-12

\section{Summary}

Deoxycytidylate (DCMP) deaminase was assayed at various times during and after normal and abnormal pregnancies. The level in amniotic fluid was assessed at induction and at caesarean section, and cord blood levels were estimated after normal delivery and at caesarean section. A rise occurred during labour and after hysterectomy and caesarean section-returning to normal after 2-3, 10, and 12 days respectively. Levels above $4.8 \times 10^{-4} \mu \mathrm{mol} \mathrm{min} \mathrm{mi}^{-1} \mathrm{ml}^{-1}$ were found in cases of preeclamptic toxaemia and early intrauterine death and in twin pregnancies over 36 weeks' gestation.

It is suggested that because of its low incidence of false-negative and false-positive results this test is far superior to other enzyme tests in pregnancy, and a further trial is in progress to assess its role.

\section{Introduction}

The relatively non-specific amino hydrolase, deoxycytidylate deaminase (DCMP deaminase, E.C. 3. 5. 4. 12) is important in the regulation of deoxynucleotide biosynthesis. It catalyses the deamination of DCMP to form deoxyuridylate. Its activity is greatly increased just before an increase in mitotic activity, as after unilateral nephrectomy (Mayfield et al., 1967) and partial hepatectomy (Maley et al., 1965). Ressler (1969) developed a sensitive method to estimate levels in human tissues and serum and Miller and Ressler (1969) estimated serum DCMP deaminase in various conditions, finding it raised in all acute liver conditions, acute infection, lupus erythematosus, after surgery, and to a lesser extent in rheumatoid arthritis and other collagen diseases. In malignant conditions about half the values were raised.

We have assessed DCMP deaminase levels in normal men and women and patients after operation. We also studied prospectively the levels during and after labour in normal and abnormal pregnancies and levels in cord serum, maternal serum, and amniotic fluid at delivery by caesarean section.

\section{Patients and Methods}

\section{CLINICAL METHODS}

Blood was taken from 20 normal men and 20 normal women and from 300 consecutive women who attended hospital as antenatal cases or were admitted as emergencies. The antenatal samples were taken at first booking, at 30-32 weeks, and at 36-38 weeks. Ten patients in whom delivery was surgically induced had serial samples taken before induction and at delivery, and their cord blood and amniotic fluid levels of DCMP deaminase were also assessed. In 10 cases in which caesarean section was performed blood was taken at delivery from cord, mother, and amniotic fluid. The 10 patients who underwent caesarean

Bronglais General Hospital, Aberystwyth, Cardiganshire SY23 1ER G. F. WILLIAMS, M.B., F.R.C.o.G., Consultant Obstetrician and Gynaecologist

D. D. JONES, M.SC., PH.D., Principal Biochemist

section and 15 patients with normal deliveries had serial estimations in the postnatal period, and 10 patients who had undergone abdominal hysterectomy also had their DMCP levels estimated, serially after operation.

Blood was obtained by venous puncture, allowed to clot, and centrifuged for three minutes. The serum was removed and the enzyme assayed within three hours of the blood being taken. No measurable loss of enzyme activity occurred, however, when serum was stored at $-20^{\circ} \mathrm{C}$ for three weeks or at $-4^{\circ} \mathrm{C}$ for one week if 1.5 $\mu \mathrm{mol}$ of $\mathrm{MgCl}_{2}, 6 \mathrm{H}_{2} \mathrm{O}$ was added to each millilitre of serum.

In the antenatal cases the biochemical results were unknown to the clinician and the clinical condition unknown to the biochemist, though this was impossible when patients were admitted to hospital.

\section{ENZYME ASSAY}

DCMP deaminase, which catalyses the conversion of DCMP to deoxyuridylate with the formation of ammonia, was assayed by a modification of the method of Ressler (1969). To avoid protein precipitation the Berthelot reaction for the direct measurement of the ammonia formed was replaced by using the catalytic effect of sodium nitroprusside on salicylate and hypochlorite to form a green compound in the presence of ammonia. The reagents for the estimation of ammonia were purchased from Hoffman-La Roche, Basle, Switzerland.

All assays were performed in duplicate. The assay mixture contained $0 \cdot 15 \mathrm{ml}$ of a $0 \cdot 15-\mathrm{M}$ phosphate buffer $\mathrm{pH} 8.0$ containing $3.0 \mu \mathrm{mol}$ $\mathrm{MgCl}_{2}, 6 \mathrm{H}_{2} \mathrm{O}$ and $16 \mathrm{mmol}$ deoxycytidine monophosphate disodium salt. To this mixture was added $0.1 \mathrm{ml}$ of serum, and the reaction was allowed to proceed for 18 hours at $22^{\circ} \mathrm{C}$. The reaction was terminated by the addition of $1 \mathrm{ml}$ salicylate solution (sodium salicylate $374 \mathrm{mmol} / 1$; sodium nitroprusside $4 \mathrm{mmol} / \mathrm{l}$ ) followed by $1 \mathrm{ml}$ of hypochlorite solution $(550 \mathrm{mmol} / 1$ in 6.25 normal sodium hydroxide). Controls were similarly treated except that the substrate solution was replaced by buffer solution containing the magnesium chloride only. After a further 10 minutes' incubation at room temperature the absorbance at $560 \mathrm{~nm}$ was read. Substrate solution was prepared freshly before enzyme assay. To calibrate the spectrophotometer standard solutions containing known amounts of ammonium sulphate were also treated as above with salicylate and hypochlorite solutions.

One unit of enzyme activity was defined as $10^{-4} \mu \mathrm{mol}$ of ammonia formed per minute per millilitre at $22^{\circ} \mathrm{C}$. To determine the reproducibility of the method a maternal serum sample was assayed 25 times and a mean ( \pm S.D.) of $3.2 \pm 0.16$ was obtained, indicating good reproducibility.

\section{Results}

We investigated 100 of our cases complying with the criteria of Letchworth et al., (1971) for a normal pregnancy to determine means and normal ranges (table I). Unlike many maternal serum enzymes DCMP deaminase did not progressively increase throughout pregnancy; neither did results in the same patient show a progressive increase.

The clinical conditions are shown against abnormal levels of DCMP deaminase in table II. Levels under 1.0 did not correlate with any clinical abnormality. A rise greater than $4.8 \times 10^{-4} \mu \mathrm{mol} \mathrm{min}^{-1}$ $\mathrm{ml}^{-1}$ was found in all patients with pre-eclamptic toxaemia, all cases of intrauterine death, and all twin pregnancies over 36 weeks' gestation. A gradual rise was found during labour. The results at induction, during labour, and at delivery in 10 patients in whom labour was surgically induced are shown in table III. Levels of DCMP deaminase were raised in amniotic fluid and maternal cord sera at caesarean section (table IV).

In women with normal deliveries the DCMP deaminase levels returned to normal after 48-72 hours, but after hysterectomy it took 10 days and after caesarean section over 12 days for levels to return to normal. 
TABLE I-Mean DCMP Deaminase Activity ( \pm S.D.) in Maternal Serum, Cord Serum, and Normal Male and Female Sera. Results are $\times 10^{-4} \mu m o l$ min ml ${ }^{-1}$ ml $^{-1}$

\begin{tabular}{|c|c|c|c|c|c|c|c|c|}
\hline & \multirow{2}{*}{$\begin{array}{l}\text { Normal } \\
\text { Men }\end{array}$} & \multirow{2}{*}{$\begin{array}{l}\text { Normal } \\
\text { Women }\end{array}$} & \multirow{2}{*}{$\begin{array}{l}\text { Cord } \\
\text { Serum }\end{array}$} & \multicolumn{4}{|c|}{ Maternal Serum at: } & \multirow[b]{2}{*}{36 Weeks } \\
\hline & & & & 20 Weeks & 24 Weeks & 28 Weeks & 32 Weeks & \\
\hline $\begin{array}{l}\text { Means } \pm \text { S.D. } \\
\text { Normal ranges }\end{array}$ & $\begin{array}{l}2 \cdot 30 \pm 0.46 \\
1 \cdot 20-3 \cdot 40\end{array}$ & $\begin{array}{l}2.31 \pm 0.47 \\
1.20-3.39\end{array}$ & $\begin{array}{l}7.90 \pm 6.90 \\
2.57-22.93\end{array}$ & $\begin{array}{l}2.90 \pm 0.78 \\
1 \cdot 20=4.79\end{array}$ & $\begin{array}{l}2.97 \pm 0.76 \\
1.20 \leq 4.79\end{array}$ & $\begin{array}{l}2.94 \pm 0.80 \\
1.05-4.79\end{array}$ & $\begin{array}{l}2.92 \pm 0.78 \\
1.05-4.68\end{array}$ & $\begin{array}{l}2.92 \pm 0.80 \\
1.05-4.79\end{array}$ \\
\hline
\end{tabular}

TABLE II-Results of 300 Cases taken through to Delivery

\begin{tabular}{|c|c|c|}
\hline $\begin{array}{l}\text { Type of Pregnancy or } \\
\text { Complication }\end{array}$ & No. of Patients & $\begin{array}{l}\text { No. with DCMP Deaminase } \\
\text { Levels }>4.8 \times 10^{-4} \mu \mathrm{mol} \\
\min ^{-1} \mathrm{ml}^{-1}\end{array}$ \\
\hline $\begin{array}{l}\text { Normal pregnancy and labour } \\
\text { Normal pregnancy and premature } \\
\text { labour } \\
\text { Essential hypertension } \\
\text { Placenta praevia } \\
\text { Accidental haemorrhage } \\
\text { Accidental haemorrhage (with pre- } \\
\text { eclampsia) } \\
\text { Postnatal hypertension } \\
\text { Multiple abnormality of fetus } \\
\text { Early (<1 weeks) intrauterine death } \\
\text { Late ( }>3 \text { weeks) intrauterine death } \\
\text { Twins (delivered before } 36 \text { weeks) } \\
\text { Twins (delivered after } 36 \text { weeks) } \\
\text { Pre-eclamptic toxaemia } \\
\text { Hypertension with superimposed } \\
\text { pre-eclampsia } \\
\text { Small-for-dates baby }\end{array}$ & $\begin{array}{r}236 \\
8 \\
8 \\
1 \\
2 \\
1 \\
1 \\
3 \\
1 \\
3 \\
1 \\
2 \\
4 \\
28 \\
1 \\
1\end{array}$ & $\begin{array}{r}1 \\
0 \\
0 \\
3 \\
0 \\
0 \\
4 \\
28\end{array}$ \\
\hline
\end{tabular}

* Three patients had levels over $4 \cdot 8$ on one occasion but reverted to normal.

\section{Discussion}

The serum level of DCMP deaminase did not seem to vary from non-pregnant values in normal pregnancies, and there was no gradual increase in an individual patient, as with many placental enzymes. Cases in which birth was overdue showed normal values. Out of 244 normal cases only three showed a falsepositive result and then only once, the levels returning to normal on subsequent testing. As the level is raised in infections a more detailed history taking may have found the cause for these rises.

Since this study a case of hepatitis without symptoms or signs was discovered by a raised DCMP deaminase level. The patient admitted five days later in labour with an intrauterine death, and liver function tests confirmed hepatitis. We now admit all patients with a raised level of DCMP deaminase until the cause is discovered or the level returns to below 4.8 . As a single test the estimation of this enzyme seems to be far superior to other enzyme tests in pregnancy, which all show a large percentage of false-positive and false-negative results.

We confirmed the rise after surgery noted by Miller and Ressler (1969) and found it applied equally to caesarean sections. The time it took for DCMP deaminase levels to return to normal after surgery-10 days for hysterectomies-was longer than four days cited by Miller and Ressler (1969) after two hernia operations.

A significant rise was found also in all patients with preeclamptic toxaemia.

The criteria for pre-eclamptic toxaemia were a rise of blood pressure in a previously normotensive patient to $140 / 90 \mathrm{~mm} \mathrm{Hg}$ with oedema or proteinuria or both. Research using renal biopsy specimens (McCartney, 1966; Fadel et al., 1970) has shown that on these criteria some patients have pre-eclampsia superimposed on chronic renal disease. All our 28 patients had DCMP deaminase levels over $4 \cdot 8$. In two patients the disease subsided on rest and the level fell below $4 \cdot 8$. They were allowed home only to return later with pre-eclampsia and raised levels of DCMP deaminase. Another patient with severe preeclampsia developed epigastric pain and vomiting and was delivered by emergency caesarean section. Her DCMP deaminase level had risen to 18. The clinically mild cases with a diastolic blood pressure of $90-100$ $\mathrm{mm} \mathrm{Hg}$ with oedema but no proteinuria had a mean level of 6.4. The severe cases with a diastolic pressure over $100 \mathrm{~mm} \mathrm{Hg}$ and albuminuria $(++)$ had a mean level of $10 \cdot 1$. The levels in patients with essential hypertension were below $4 \cdot 8$. This difference from patients with preeclamptic toxaemia has been shown with serum levels of $\beta$-glucuronidase (McDonald and Odell, 1947), cystine aminopeptidase (Hurry et al., 1972), and, to a lesser degree, uric acid (Pollak and Nettles, 1960).

The single case of essential hypertension with superimposed pre-eclamptic toxaemia showed the rise before the criteria for this condition were reached, but normally patients with preeclampsia had to fulfil all the criteria before a rise over 4.8 occurred. This suggests that the test will not foretell those

TABLE III-DCMP Deaminase Levels at Various Times in 10 Patients in whom delivery was Surgically induced

\begin{tabular}{|c|c|c|c|c|c|}
\hline Case No. & $\begin{array}{l}\text { Amniotic-fluid } \\
\text { Level at } \\
\text { Induction }\end{array}$ & $\begin{array}{l}\text { Maternal Level } \\
\text { during Labour }\end{array}$ & $\begin{array}{l}\text { Maternal Level } \\
\text { at Delivery }\end{array}$ & $\begin{array}{c}\text { Cord-blood } \\
\text { Level }\end{array}$ & $\begin{array}{l}\text { Length of Labour } \\
\text { from Onset to } \\
\text { Contraction (Hours) }\end{array}$ \\
\hline $\begin{array}{r}1 \\
2 \\
3 \\
4 \\
5 \\
6 \\
7 \\
8 \\
9 \\
10\end{array}$ & $\begin{array}{l}2 \cdot 7 \\
1.5 \\
3 \cdot 6 \\
6.9 \\
3.7 \\
4.9 \\
4 \cdot 4 \\
3 \cdot 2 \\
3 \cdot 2 \\
3 \cdot 4\end{array}$ & $\begin{array}{l}5.4 \\
5.7 \\
\\
6.9\end{array}$ & $\begin{array}{r}6.7 \\
3.3 \\
5.0 \\
8.9 \\
5.0 \\
5.9 \\
7.5 \\
7.7 \\
5.7 \\
10.0\end{array}$ & $\begin{array}{r}1.5 \\
19.7 \\
3.5 \\
8.3 \\
5.8 \\
4.8 \\
6.3 \\
10.5 \\
3.6 \\
3.8\end{array}$ & $\begin{array}{c}2 \\
3 \\
2 \\
7 \\
1 \frac{1}{2} \\
8 \\
36 \\
3 \frac{1}{2} \\
3 \frac{1}{2} \\
24\end{array}$ \\
\hline
\end{tabular}

TABLE IV-DCMP Deaminase Levels at Caesarean Section in 10 patients

\begin{tabular}{|c|c|c|c|c|}
\hline Case No. & Maternal Level & Cord-blood Level & Amniotic-fluid Level & Remarks \\
\hline $\begin{array}{l}11 \\
12 \\
13 \\
14 \\
15 \\
16 \\
17 \\
18 \\
19 \\
20\end{array}$ & $\begin{array}{r}3.1 \\
2.8 \\
5.4 \\
1.9 \\
3.7 \\
6.2 \\
18.1 \\
5.3 \\
9.5 \\
5.6\end{array}$ & $\begin{array}{l}5 \cdot 7 \\
5 \cdot 9 \\
4.9 \\
1 \cdot 4 \\
4 \cdot 5 \\
3 \cdot 4 \\
3 \cdot 2 \\
2 \cdot 2 \\
6.8 \\
3 \cdot 2\end{array}$ & $\begin{array}{r}5.2 \\
0.6 \\
8.5 \\
46 \\
0.9 \\
23.6 \\
1.5 \\
1.9 \\
5.7 \\
5.8\end{array}$ & $\begin{array}{l}\text { Elective caesarean section } \\
\text { Elective caesarean section } \\
\text { Pre-eclamptic toxaemia } \\
\text { In labour before caesarean section } \\
\text { Elective caesarean section } \\
\text { In labour before caesarean section } \\
\text { Severe pre-eclamptic toxaemia } \\
\text { Elective caesarean section } \\
\text { In labour before caesarean section } \\
\text { Pre-eclamptic toxaemia, elective } \\
\text { caesarean section }\end{array}$ \\
\hline
\end{tabular}


patients at risk. A larger blind study of pre-eclamptic cases is now in progress with another centre to try to relate the levels to the severity of the condition and to the wellbeing of the fetus.

DCMP deaminase is excreted in both maternal and fetal urines. Maternal and cord sera levels in both caesarean section cases and normal deliveries seemed to be quite independent of each other. The rise in the maternal serum during labour did not seem to be related to the length or severity of labour. The amniotic-fluid levels were also not related to the maternal or cord levels.

We thank Mrs. L. Targett-Adams for performing most of the estimations and the Welsh Research Committee for a research grant.

\section{References}

Fadel, H. E., et al. (1970). Die Spatgestose, ed. E. T. Rippmann, p. 28. Basle, Schwabe.

Hurry, D. J., et al. (1972). Fournal of Obstetrics and Gynaecology of the British Commonwealth, 79, 792 .

Letchworth, A. T., et al. (1971). Fournal of Obstetrics and Gynaecology of the British Commonwealth, 78, 542.

Maley, F. G., Lorenson, M. F., and Maley, F. (1965). Biochemical and Biophysical Research Communications, 18, 364.

Mayfield, E. D., jun., Liebelt, R. A., and Bresnick, E. (1967). Cancer Research, 27, 1652.

McCartney, C. P. (1966). Clinica Obstetrica e Ginecologica, 9, 864

McDonald, D. F., and Odell, L. D. (1947). Fournal of Clinical Endocrinology

7, 535.

Pollak, V. E., and Nettles, J. B. (1960). Medicine, 39, 469.

Ressler, N. (1969). Clinical Chemistry, 15, 575.

\title{
Falciparum Malaria Semi-resistant to Clindamycin
}

\author{
A. P. HALL, \\ E. B. DOBERSTYN, \\ A. NANAKORN, \\ P. SONKOM
}

British Medical fournal, 1975, 2, 12-14

\section{Summary}

Clindamycin, a semi-synthetic antibiotic of the lincomycin family, at a dose of $\mathbf{4 5 0} \mathrm{mg}$ eight-hourly for three days in adults cured five out of 10 patients moderately ill with chloroquine-resistant falciparum malaria. Combination therapy with full-dose quinine and clindamycin for three days cured all four patients so treated who were followed up, and with half dosage three out of five patients were cured. Both combinations, however, caused upper gastrointestinal toxicity and appeared to potentiate both toxicity and possibly antimalarial efficacy. Colitis due to clindamycin was not observed. Sequential therapy was not toxic and could be useful in patients who have relapsed after more conventional treatment.

\section{Introduction \\ Chloroquine-resistant falciparum malaria responds to few drugs and new drugs are needed. The antimalarial activity of a group of chlorinated lincomycin analogues was first demon- strated in mice infected with Plasmodium berghei (Lewis, 1968) and in monkeys infected with $P$. cynomolgi (Powers, 1969; Schmidt et al., 1970). Chloroquine-resistant $P$. falciparum in- fections in owl monkeys were also cured by these compounds (Powers and Jacobs, 1972). Both in animals and in man in- fected with malaria clindamycin acted slowly (Miller et al., 1974). Three day courses of quinine and clindamycin given in combination or sequentially, however, proved effective against chloroquine-resistant falciparum malaria in volunteers (Miller et al., 1974). We tested clindamycin alone and in combination with quinine in Thais naturally infected with chloroquine- resistant falciparum malaria.}

U.S. Army Medical Component, S.E.A.T.O., Bangkok, Thailand A. P. HALL, M.B., F.A.C.P., Colonel, M.C., Chief of Department of M DOBER

政, Assistant Chief

A. NANAKORN, Medical Technician

Trad Provincial Hospital, Thailand

P. SONKOM, M.D., Medical Director

\section{Methods}

The study was performed at the Trad Provincial Hospital in southeast Thailand. The research methods have been described elsewhere (Hall et al., 1975 a). We operated a daily malaria clinic at the hospital and suitable outpatients volunteered for the inpatient studies. Male patients with an asexual parasite count over $1 \times 10^{\circ} / 1$ were included. Informed consent was obtained in all cases. To avoid the problem of immunity patients with clinically mild infections were rarely studied.

Quantitative parasite counts were made at least twice daily in hospital on blood specimens obtained by finger-prick at 07.00 and 14.00 hours and at follow-up examinations on days 14,21 , and 28 . Determination of the packed cell volume and leucocyte count was made on admission and whenever clinically indicated. Sera were collected on admission and the concentrations of bilirubin and creatinine determined.

Throughout the study the drugs were administered by one of the study physicians during medication ward rounds, usually at 06.00 , 14.00 , and 21.00 hours. The patients were observed by the physician as they swallowed the drug with water and then examined and kept under observation for a few minutes. The clindamycin was dispensed as $150-\mathrm{mg}$ capsules, the usual dose being $\mathbf{4 5 0} \mathrm{mg}$ every eight hours for three days (total dose $4050 \mathrm{mg}$ ). The quinine was administered as sugar-coated tablets of quinine sulphate (U.S.P.), each containing $270 \mathrm{mg}$ base. The usual dose was $\mathbf{5 4 0} \mathrm{mg}$ every eight hours for three days (total dose $4860 \mathrm{mg}$ ).

Follow-up examinations on days 14, 21, and 28 were made either in the clinic or at home. In evaluating the final therapeutic result in each patient the W.H.O. (1967) classification was used (see table I). A patient was regarded as radically cured when the parasita mia was cleared and had not reappeared before day 29. Parasite clearance times were measured in hours. Fever clearance times were measured (in hours) when the initial fever was at least $38 \cdot 0^{\circ} \mathrm{C}$. Clearance of fever was so defined when the temperature fell to $37 \cdot 2^{\circ} \mathrm{C}$ or less and remained at that level for at least one more reading. If the fever or parasitaemia persisted at the time of discharge at least 100 hours after admission the elapsed time was arbitrarily regarded as the clearance time.

\section{Results}

\section{CLINDAMYCIN}

Twelve patients (cases 1-12) were treated with clindamycin alone (table I); 11 received $450 \mathrm{mg}$ every eight hours for three days, and one (case 4), a 12-year-old boy weighing $28 \mathrm{~kg}$, received $300 \mathrm{mg}$ every eight hours. In five patients not responding to clindamycin a more effective regimen was substituted.

The initial clinical response was fairly rapid in some of the patients (table I) but the mean parasite and fever clearance times were slow (88 and 68 hours respectively). In five patients 